\title{
KUALITAS FISIK GELATIN HASIL EKSTRAKSI KULIT SAPI DENGAN LAMA PERENDAMAN DAN KONSENTRASI ASAM KLORIDA (HCl) YANG BERBEDA
}

\author{
RAPIKA, ZULFIKAR, DAN ZUMARNI \\ Laboratorium Teknologi Pasca Panen Fakultas Pertanian dan Peternakan \\ Universitas Islam Negeri Sultan Syarif Kasim Riau \\ email :Rapika@yahoo.ac.id
}

\begin{abstract}
Gelatin is a compound hydrolysis of collagen fibers. The purpose of this research was to determine the influence of concentration of hydrochloric acid $(\mathrm{HCl})$. and soaking time on the bovine hide making toward physical quality gelatin. The materials were bovine hide, hydrochloric acid and distilled water. Data were statistically analyzed by A Completely Random Design with factorial pattern consist two factors; hydrochloric acid concentration (3\% and 5\%) and soaking time $(4,8,12$ and 16 hours) with three times replications. Parameters measured were $p H$, gel strength, yield and viscosity. The result showed that $\mathrm{pH}$, bloom strogh, yield and viscosity, centipoise $(\mathrm{cP})$ of gelatin was 2.70-4.12, 53,33-185,00 $\mathrm{g}, 18.04-37.93 \%$ and 1.49-1,79, respectively. An interaction between hydrochloric acid and soaking time significantly $(P<0.01)$ influence in following categories: $\mathrm{T} \mathrm{pH}$, gel strength, viscosity and yield. It is conclude that the best combination treatments is $\mathrm{HCl} 3 \%$ and 12 hours of soaking soaking.
\end{abstract}

Keywords : gelatin of bovine hide, hydrochloric acid

\section{PENDAHULUAN}

Salah satu kebutuhan gizi masyarakat Indonesia adalah daging dari ternak potong. Populasi ternak sapi secara Nasional pada tahun 2010 berjumlah 12.749.696 ekor meningkat pada tahun 2011 berjumlah 14.824.373 ekor (Badan Pusat Statistik (BPS, 2012). Konsumsi ternak tidak lepas dari masalah kulit yang dihasilkan, sehingga bisa dimanfaatkan untuk gelatin.

Kulit merupakan hasil samping dari pemotongan hewan yang berupa organ tubuh bagian terluar yang dipisahkan dari tubuh pada saat proses pengulitan. Kulit mentah dibedakan atas dua kelompok, yaitu kelompok kulit yang berasal dari hewan besar seperti sapi, kerbau dan lainlain, yang dalam istilah asing disebut hides dan kelompok kulit yang berasal dari hewan kecil seperti kambing, kelinci, dan lain-lain yang dalam istilah asing disebut skins. Kulit hewan besar lebih banyak mengandung protein, lemak dan khitin dibanding kulit hewan kecil.

Gelatin merupakan molekul polipeptida yang berasal dari kolagen yang merupakan protein utama penyusun jaringan hewan (kulit dan tulang). Gelatin banyak digunakan dalam industri sebagai bahan tambahan yang berfungsi sebagai stabilizer dan emulsifier sehingga dapat membuat dan mempertahankan sistem emulsi. Industri yang menggunakannya meliputi industri pangan, farmasi, kosmetika dan fotografi.

Gelatin masih merupakan barang impor di Indonesia, dimana Negara pengimpor utama adalah Eropa dan Amerika. Menurut data BPS (2007) pada tahun 2006 jumlah gelatin yang diimpor Indonesia adalah 3.304 ton dan angka itu diperkirakan akan terus meningkat seiring dengan pertambahan penduduk dan meningkatnya kebutuhan akan gelatin. Gelatin yang dipasarkan di Indonesia masih didominasi oleh gelatin impor. Menurut Karim (2009) gelatin impor yang dipasarkan di dunia (termasuk Indonesia) bahan bakunya diduga berasal dari kulit babi $(46 \%)$ maupun kulit sapi $(29,4 \%)$ dan tulang sapi $(23,1 \%)$ serta sumber lain (1,5\%). Penggunaan bahan baku dari kulit babi tentu merupakan masalah bagimasyarakat di Indonesia yang mayoritas beragama Islam. 
Menurut Hinterwaldner (1977) Konsentrasi $\mathrm{HCl}$ 5\% akan menghasilkan laju hidrolisis protein yang cepat. Proses asam yang bias digunakan adalah asam sulfat, asam fosfat, dan asam klorida, tetapi yang paling baik dan umum digunakan adalah asam klorida. Waktu yang dibutuhkan dalam proses asam umumnya 2-48 jam jauh lebih cepat dibandingkan dengan proses basa yaitu sekitar 3 bulan (Hinterwaldner, 1977).

Menurut Utama (1997) larutan asam mampu mengubah serat kolagen tripel heliks menjadi rantai tunggal dalam waktu singkat, sehingga pada waktu yang sama jumlah kolagen yang terhidrolisis lebih banyak. Perendaman dalam larutan asam terhadap kolagen dapat menghasilkan polimer gelatin dengan glisin sebagai penyusun utama (Gomez et al., 2004).

Mengingat manfaat gelatin yang sangat luas dan diimpor dari luar negeri dengan bahan baku utamanya non halal, maka perlu dicari alternatif lain untuk menghasilkan gelatin dengan memanfaatkan bahan-bahan yang tersedia di Indonesia dan sudah jelas status kehalalannya. Salah satu bahan baku untuk sumber gelatin yang dapat digunakan adalah berasal dari kulit sapi dengan perendaman $\mathrm{HCl} 3 \%$ dan 5\%.

\section{MATERI DAN METODE}

Penelitian ini telah dilaksanakan pada bulan Maret sampai April 2015 di Laboratorium Pascapanen Fakultas Pertanian dan Peternakan Universitas Islam Negeri Sultan Syarif Kasim Riau.

\section{Alat dan Bahan Penelitian}

Peralatan yang digunakan dalam penelitian adalah peralatan untuk proses pembuatan gelatin seperti toples untuk merebus, mangkuk tempat bahan, kain kasa, waterbath, $\mathrm{pH}$ meter, viscometer, texture analyzer dan oven. Bahan dasar pembuatan gelatin kulit sapi adalah kulit sapi Brahman Cross yang berasal dari
Rumah Pemotongan Hewan (RPH) Pekanbaru, aquades, $\mathrm{HCl} 3 \%$ dan 5\%.

\section{Metode Penelitian}

Rancangan percobaan yang digunakan adalah Rancangan Acak Lengkap pola faktorial dengan dua faktor yaitu kosentrasi $\mathrm{HCl}(3 \%$ dan 5\%) dan lama perendaman $(4,8,12$ dan 16 jam) dengan 3 ulangan sehingga terdapat 24 unit perlakuan.

\section{Prosedur Penelitian}

Penelitian dilakukan sesuai dengan prosedur pembuatan ekstrak gelatin kulit sapi, pengolahan sampai tahap analisis variabel penelitian.

Tahap pembuatan gelatin kulit sapi :

1. Penyiapan bahan baku, terdiri atas pembersihan kulit sapi dari lemak dan bulu dengan cara membakar dan dihilangkan bulu menggunakan pisau. Hal ini bertujuan untuk menghilangkan sebagian dari lemak yang berlebihan dan kotoran-kotoran yang menempel pada kulit agar bisa terlepas, sehingga tidak mengganggu proses berikutnya. Kemudian kulit dipotong ukuran 3-4 cm lalu dicuci dengan air suling sampai bersih, setelah itu kulit ditimbang sebanyak $500 \mathrm{~g}$

2. Tahap perendaman dalam $\mathrm{HCl} 3 \%$ dan $5 \%$.

Selanjutnya kulit direndam dalam $\mathrm{HCl}$ $3 \%$ dan $5 \%$ sesuai dengan variabel yang dikerjakan.

3. Tahap pencucian

Kulit yang telah direndam dalam $\mathrm{HCl}$ $3 \%$ dan $5 \%$ selanjutnya dicuci dengan air mengalir sampai $\mathrm{pH} 4-5$.

4. Tahap ekstraksi

Setelah selesai dicuci kemudian diekstrak. Proses ekstraksi dimulai dengan menempatkan kulit dalam toples kaca dan ditambahkan aquades $1.000 \mathrm{~mL}$, kemudian dipanaskan dalam shaker bath pada suhu $70^{\circ} \mathrm{C}$. Pemanasan ini akan menghasilkan larutan gelatin 
dan sisa ossein. Keduanya dipisahkan menggunakan saring atau kain kasa.

5. Tahap pembekuan

Setelah selesai disaring kemudian dilakukan proses pembekuan di dalam kulkas.

6. Tahap pengeringan

Selanjutnya dilakukan pengeringan gelatin dengan memasukkan gelatin ke dalam oven selama 72 jam.

7. Tahap penggilingan

Setelah selesai dioven kepingan gelatin tersebut digiling menggunakan blender sampai kepingan gelatin menjadi tepung gelatin.
8. Tahap analisis

Setelah proses ekstraksi selesai dan mendapatkan hasil tepung gelatin kemudian hasil produk gelatin ini di analisis sifat fisik.

\section{HASIL PEMBAHASAN}

\section{Nilai pH Gelatin Kulit Sapi}

Nilai $\mathrm{pH}$ (derajat keasaman) gelatin merupakan salah satu parameter yang penting dalam standar mutu gelatin. Nilai $\mathrm{pH}$ gelatin kulit sapi yang direndam menggunakan $\mathrm{HCl} 3 \%$ dan 5\% selama 4, 8, 12 dan 16 jam disajikan pada Tabel 1.

Tabel 1 Rata-rata nilai $\mathrm{pH}$ gelatin kulit sapi pada konsentrasi $\mathrm{HCl}$ dan lama perendaman yang berbeda.

\begin{tabular}{cccccc}
\hline \multirow{2}{*}{ Konsentrasi $\mathrm{HCl}$} & \multicolumn{4}{c}{ Lama Perendaman (Jam) } & \multirow{2}{*}{ Rataan } \\
\cline { 2 - 4 } & 4 & 8 & 12 & 16 & \\
\hline $3 \%$ & $4,12^{\mathrm{f}}$ & $3,32^{\text {bcde }}$ & $3,11^{\text {bcd }}$ & $3,08^{\text {bc }}$ & 3,41 \\
$5 \%$ & $3,55^{\mathrm{e}}$ & $3,24^{\text {bcde }}$ & $3,07^{\mathrm{b}}$ & $2,70^{\mathrm{a}}$ & \multirow{2}{*}{3,14} \\
\hline Rataan & 3,83 & 3,28 & 3,09 & 2,89 & \\
\hline
\end{tabular}

Keterangan : Superskrip yang beda menunjukkan berbeda nyata $(\mathrm{P}<0,05)$.

Hasil analisis data pada Tabel 1 menunjukan interaksi, konsentrasi $\mathrm{HCl}$ dan lama perendaman berbeda sangat nyata $(\mathrm{P}<0,05)$ terhadap nilai $\mathrm{pH}$ gelatin kulit sapi. Nilai $\mathrm{pH}$ yang diperoleh dari penelitian ini berkisar 2,70-4,12 Hasil penelitian ini di bawah standar gelatin hasil proses asam yang diterapkan oleh GMIA (2012) yaitu 3,8-5,5. Menurut Ward dan Courts (1977) nilai pH gelatin komersial berkisar 4-7.

Konsentrasi $\mathrm{HCl} 3 \%$ dengan lama perendaman 4 jam menghasilkan nilai $\mathrm{pH}$ yang tinggi yaitu 4,12 semakin rendah konsentrasi dan semakin singkat waktu perendaman akan menghasilkan nilai $\mathrm{pH}$ yang baik karena asam klorida yang digunakan saat perendaman tidak terserap ke dalam jaringan fibril kolagen sehingga pada saat pencucian kulit asam klorida mudah hilang dari kulit tersebut.

Konsentrasi $\mathrm{HCl} 3 \%$ dan 5\% pada perendaman 8 dan 12 jam tidak berbeda nyata $(\mathrm{P}>0,05)$ karena semakin lama perendaman maka semakin banyak asam klorida yang masuk ke dalam jaringan fibril kolagen dan ikut diekstraksi sehingga menghasilkan nilai $\mathrm{pH}$ gelatin kulit sapi yang rendah.

Interaksi antara proses asam dengan lama perendaman berbeda nyata $(\mathrm{P}<0,05)$ terhadap nilai $\mathrm{pH}$ gelatin kulit sapi, semakin tinggi konsentrasi dan semakin lama perendaman akan menurunkan nilai $\mathrm{pH}$. Konsentrasi $\mathrm{HCl} 5 \%$ dengan lama perendaman 16 jam memberikan nilai $\mathrm{pH}$ terendah yaitu 2,70, sedangkan konsentrasi $\mathrm{HCl} 3 \%$ dengan lama perendaman 4 jam menghasilkan nilai $\mathrm{pH}$ tertinggi yaitu 4,12.

Rendahnya $\mathrm{pH}$ gelatin kulit sapi yang dihasilkan disebabkan konsentrasi $\mathrm{HCl}$ dan waktu perendaman yang semakin lama semakin banyak asam yang masuk ke dalam jaringan fibril kolagen dan ikut diekstraksi. Hal ini sesuai dengan penelitian Huda (2013) bahwa gelatin yang dihasilkan melalui proses asam dengan 
perendaman yang lebih lama maka derajat keasamanya akan semakin meningkat.

\section{Kekuatan Gel Gelatin Kulit Sapi}

Kekuatan gel gelatin atau dikenal dengan istilah bloom adalah salah satu parameter dari tekstur dan merupakan gaya untuk menghasilkan deformasi tertentu (de Man, 1989). Kekuatan gel gelatin kulit sapi yang direndam menggunakan $\mathrm{HCl} 3 \%$ dan 5\% selama 4, 8, 12 dan 16 jam disajikan pada Tabel 2 .

Tabel 2. Rata-rata nilai kekuatan gel gelatin kulit sapi pada konsentrasi $\mathrm{HCl}$ dan lama perendaman yang berbeda.

\begin{tabular}{cccccc}
\hline Konsentrasi & \multicolumn{4}{c}{ Lama Perendaman (Jam) } & \multirow{2}{*}{ Rataan } \\
\cline { 2 - 4 } HCl & 4 & 8 & 12 & 16 & \\
\hline $3 \%$ & $114,67^{\mathrm{d}}$ & $130,33^{\mathrm{e}}$ & $185,00^{\mathrm{f}}$ & $97,00^{\mathrm{c}}$ & 131,75 \\
$5 \%$ & $62,67^{\mathrm{a}}$ & $140,67^{\mathrm{e}}$ & $80,00^{\mathrm{b}}$ & $53,33^{\mathrm{a}}$ & 84,17 \\
\hline Rataan & 88,67 & 135,5 & 132,5 & 75,17 & \\
\hline
\end{tabular}

Keterangan : Superskrip yang beda menunjukkan berbeda sangat nyata $(\mathrm{P}<0,01)$

Hasil analisis data pada Tabel 2 menunjukan interaksi konsentrasi $\mathrm{HCl}$ dan lama perendaman pada penelitian ini berbeda sangat nyata $(\mathrm{P}<0,01)$ terhadap kekuatan gel. Nilai kekuatan gel yang diperoleh dari penelitian ini berkisar 53,33-185,00 g/bloom. Menurut Ward dan Courts (1977), kekuatan gel tergantung dari panjang rantai asam aminonya. Jika kondisi kolagennya telah dihidrolisis secara sempurna, maka kekuatan gel dapat meningkat.

Semakin tinggi konsentrasi $\mathrm{HCl}$ dan semakin lama perendaman akan mempengaruhi nilai kekuatan gel gelatin kulit sapi. Konsentrasi $\mathrm{HCl} \mathrm{5 \%} \mathrm{dengan}$ lama perendaman 16 jam menghasilkan nilai kekuatan gel terendah yaitu 53,33 g/Bloom karena pada konsentrasi 5\% dengan lama perendaman 16 jam rantai kolagen telah putus dan gelatin tersebut larut kedalam $\mathrm{HCl}$ sehingga kekuatan gel yang dihasilkan rendah, sedangkan konsentrasi $\mathrm{HCl} 3 \%$ dengan lama perendaman 12 jam menghasilkan nilai kekuatan gel tertinggi yaitu 185,00 $\mathrm{g} /$ Bloom karena pemutusan kolagen yang sempurna sehingga kekuatan gel yang dihasilkan tinggi. Menurut Ward dan Courts (1977), kekuatan gel tergantung dari panjang rantai asam amino, Jika kondisi kolagennya telah dihidrolisis secara sempurna, maka kekuatan gel dapat meningkat, karena hidrolisis kolagen yang sempurna dapat menghasilkan rantai polipeptida yang panjang.

\section{Viskositas Gelatin Kulit Sapi}

Viskositas (kekentalan) gelatin merupakan salah satu sifat fisik gelatin yang cukup penting. Pengujian viskositas dilakukan untuk mengetahui tingkat kekentalan gelatin sebagai larutan pada konsentrasi dan suhu tertentu (Rusli, 2004). Viskositas gelatin kulit sapi yang direndam menggunakan $\mathrm{HCl} 3 \%$ dan 5\% selama 4, 8, 12 dan 16 jam disajikan pada Tabel 3.

Tabel 3 Nilai rata-rata Viskositas $(\mathrm{cP})$ gelatin kulit sapi pada konsentrasi $\mathrm{HCl}$ dan lama perendaman yang berbeda.

\begin{tabular}{cccccc}
\hline \multirow{2}{*}{ Konsentrasi HCl } & \multicolumn{4}{c}{ Lama Perendaman (Jam) } & \multirow{2}{*}{ Rataan } \\
\cline { 2 - 5 } & 4 & 8 & 12 & 16 & 1,59 \\
\hline $3 \%$ & $1,52^{\mathrm{a}}$ & $1,53^{\mathrm{a}}$ & $1,79^{\mathrm{c}}$ & $1,50^{\mathrm{a}}$ & 1,53 \\
\hline Rataan & $1,51^{\mathrm{a}}$ & $1,60^{\mathrm{b}}$ & $1,50^{\mathrm{a}}$ & $1,49^{\mathrm{a}}$ & \\
\hline
\end{tabular}

Keterangan : Superskrip yang beda menunjukkan berbeda sangat nyata $(\mathrm{P}<0,01)$ 
Hasil analisis data pada Tabel 3 menunjukan interaksi konsentrasi $\mathrm{HCl}$ dan lama perendaman berbeda sangat nyata $(\mathrm{P}<0,01)$ terhadap nilai viskositas gelatin kulit sapi. Nilai viskositas yang diperoleh dari penelitian ini berkisar 1,49-1,79 cP nilai viskositas yang dihasilkan dalam penelitian ini memenuhi standar yang ditetapkan GMIA (2012) yaitu 1,5-7,5 cP.

Konsentrasi $\mathrm{HCl} 5 \%$ pada perendaman 8 jam menghasilkan nilai viskositas yang tinggi yaitu $1,60 \mathrm{cP}$. Tingginya nilai viskositas dipengaruhi oleh berat molekul dan panjang rantai asam amino gelatin serta pemutusan rantai kolagen yang sempurna. Konsentrasi $\mathrm{HCl} \mathrm{3 \%}$ dengan lama perendaman 4, 8 dan 16 jam serta konsentrasi $\mathrm{HCl} 5 \%$ pada perendaman 4, 12 dan 16 jam tidak berbeda nyata $(P>0,01)$.

Semakin tinggi konsentrasi $\mathrm{HCl}$ dan semakin lama perendaman akan mempengaruhi nilai viskositas gelatin kulit sapi. Konsentrasi $\mathrm{HCl} \mathrm{5 \%} \mathrm{dengan} \mathrm{lama}$ perendaman 16 jam menghasilkan nilai viskositas terendah yaitu 1,49 cP. Avena et al. (2006) menyatakan semakin kecil berat molekul dari gelatin juga menyebabkan distribusi molekul gelatin dalam larutan semakin cepat sehingga menghasilkan nilai viskositas yang rendah. Konsentrasi $\mathrm{HCl} 3 \%$ dengan lama perendaman 12 jam menghasilkan nilai viskositas tinggi yaitu 1,79 cP.

\section{Nilai Rendemen Gelatin Kulit Sapi}

Rendemen merupakan persentase gelatin yang dihitung berdasarkan perbandingan antara gelatin serbuk yang dihasilkan dengan berat bahan baku (kulit sapi) yang telah dibersihkan. Semakin banyak rendemen yang dihasilkan maka semakin efisien perlakuan yang diterapkan (Mwanda dan Simpen, 2008). Rendemen gelatin kulit sapi yang direndam menggunakan $\mathrm{HCl} 3 \%$ dan 5\% selama 4,8,12 dan 16 jam disajikan pada Tabel 4 .

Tabel 4. Nilai rata-rata rendemen (\%) gelatin kulit sapi pada konsentrasi $\mathrm{HCl}$ dan lama perendaman yang berbeda

\begin{tabular}{|c|c|c|c|c|c|}
\hline \multirow{2}{*}{ Konsentrasi $\mathrm{HCl}$} & \multicolumn{4}{|c|}{ Lama Perendaman (jam) } & \multirow{2}{*}{ Rataan } \\
\hline & 4 & 8 & 12 & 16 & \\
\hline $3 \%$ & $24,59 \mathrm{bcd}$ & $30,89 \mathrm{~cd}$ & $37,93 \mathrm{e}$ & $27,42^{\mathrm{cd}}$ & 30,21 \\
\hline $5 \%$ & $24,42^{\mathrm{bc}}$ & $28,90 \mathrm{~cd}$ & $21,54^{\mathrm{ab}}$ & $18,04^{\mathrm{a}}$ & 23,23 \\
\hline Rataan & 24,51 & 29,89 & 29,74 & 22,73 & \\
\hline
\end{tabular}

Keterangan : Superskrip yang beda menunjukkan berbeda sangat nyata $(\mathrm{P}<0,01)$

Hasil analisis data pada Tabel 4 menunjukan interaksi konsentrasi $\mathrm{HCl}$ dan lama perendaman berbeda sangat nyata $(\mathrm{P}<0,01)$ terhadap nilai rendemen gelatin kulit sapi. Nilai rendemen yang dihasilkan dalam penelitian ini berkisar 18,04-37,93\%. Semakin tinggi konsentrasi $\mathrm{HCl}$ dan semakin lama perendaman akan mempengaruhi nilai rendemen gelatin kulit sapi.

Konsentrasi $\mathrm{HCl} 5 \%$ dengan lama perendaman 16 jam menghasilkan nilai rendemen terendah yaitu $18,04 \%$ hal ini disebabkan meningkatnya konsentrasi $\mathrm{HCl}$ akan mempercepat laju hidrolisis kolagen dan semakin lama perendaman akan mengakibatkan kolagen terhidrolisis sehingga mengembang dan menyebar dalam larutan asam sedangkan perlakuan terbaik berada pada konsentrasi $\mathrm{HCl} 3 \%$ dengan lama perendaman 12 jam menghasilkan nilai rendemen tinggi yaitu 37,93\%. Menurut Kolodziejska et al., (2007) terjadi peningkatan rendemen berkaitan dengan banyaknya jumlah kolagen yang dikonversi dan mengalami transformasi menjadi gelatin. Hasil penelitian ini sesuai dengan penelitian (Santoso, 2001) semakin tinggi konsentrasi dan lama perendaman maka nilai rendemen akan semakin menurun. Konsentrasi $\mathrm{HCl} 3 \%$ dengan lama perendaman 4, 8 dan 16 jam serta konsentrasi $\mathrm{HCl} 5 \%$ dengan lama 
perendaman 4, 8 dan 12 jam rendemen yang dihasilkan tidak berbeda nyata.

\section{KESIMPULAN}

1. Interaksi konsentrasi $\mathrm{HCl}$ dan lama perendaman berpengaruh terhadap $\mathrm{pH}$, kekuatan gel, viskositas dan rendemen.

2. Gelatin kulit sapi dihasilkan dari konsentrasi $\mathrm{HCl} 3 \%$ dan lama perendaman 4 jam dengan nilai $\mathrm{pH}$ 2,70 dan konsentrasi $\mathrm{HCl} 5 \%$ dengan lama perendaman 16 jam menghasilkan nilai pH 4,12. Konsentrasi $\mathrm{HCl} 5 \%$ dan lama perendaman 12 jam dan konsentrasi $\mathrm{HCl} 3 \%$ dengan lama perendaman 16 jam menghasilkan kekuatan gel 53.33-185.00 g/bloom, viskositas 1,49-1,79 cP, rendemen18,04-37,93\%.

3. Kombinasi perlakuan terbaik adalah konsentrasi $\mathrm{HCl} 3 \%$ dengan lama perendaman 12 jam menghasilkan kualitas fisik terbaik dengan nilai rendemen yaitu 37,93\% dengan kekuatan gel yaitu 185,00 g/bloom dan viskositas $1,79 \mathrm{cP}$.

\section{SARAN}

Perlu dilakukan penelitian lebih lanjut mengenai parameter-parameter seperti warna dan kelarutan dalam air sehingga menghasilkan gelatin yang berkualitas yang baik. Perendaman sebaiknya dilakukan selama 12 jam pada konsentrasi $\mathrm{HCl} 3 \%$ untuk memperoleh gelatin kulit sapi dengan hasil yang efisien.

\section{DAFTAR PUSTAKA}

Avena-Bustillos RJ. 2006. Water vapor permeability of mamalian and fish gelatin films. Journal of Food Science. 71(4):202-207.

Badan Pusat Statistik (BPS). 2007. Data Ekspor Impor Indonesia. BPS. Jakarta.
Badan Pusat Statistik (BPS). 2012. Perkembangan Beberapa Indikator Utama Sosial Ekonomi Indonesia. BPS. Statistik Indonesia. Jakarta.

de Man, J. M. 1989. Kimia Makanan. Edisi Kedua. Padmawinata K, penerjemah. ITB. Bandung. Terjemahan dari Principle of Food Chemistry.

Gelatin Manufactures Institute of America (GMIA). 2012. Gelatin Handbook. Gelatin Manufactures Institute of America. http://www.gelatingmia.com/images/GMIA_Gelatin_Manual_2012 .pdf. Diakses 18 maret 2014

Gomez-Guillen, M.C., Gimenez, B., and Montero, P. 2004. Extraction of gelatin from fish skins by high pressure treatment. Abstract. Food Hidrocolloids. Science Direct, 19(5): 923-928.

Hinterwaldner, R. 1977. Raw Material. Di dalam Ward AG dan Courts A (ed). 1977. The Science and Technology of Gelatin. Academic Press. New York

Huda, W. H., W. Atmaka., E. Nurhartadi. 2013. kajian karakteristik fisik dan kimia gelatin ekstrak tulang kaki ayam (Gallus gallus bankiva) dengan variasi lama perendaman dan konsentrasi asam. Jurnal Teknosains Pangan. 2(3):70-75.

Karim, A. A, dan Bhat, R. 2009. Review Fish Gelatin. properties challenges and prospectes as an alternative to mammalian gelatins. Trends In Food Science And Technology, 19: 644-656.

Kolodziejska, I., E. Skierka., M. Sadowo., W. Kolodziejska and C. Niecikowska. 2007. Effect of Extracting time and Temperature on $\mathrm{y}$ Kolodziejskaield of gelatin from different fish offal. Food Chem.107(2):700706.

Miwada, S dan Simpen. 2008. Optimalisasi Potensi Ceker Ayam (Shank) Hasil Limbah RPH Melalui Metode Ekstraksi Termodifikasi untuk Menghasilkan Gelatin. Universitas Udayana. Denpasar. 
Rusli A. 2004. Kajian proses ekstraksi gelatin dari kulit ikan patin (Pangasius hypopthalmus) segar [tesis]. Sekolah Pascasarjana. IPB. Bogor:

Santoso, A.W. 2001. Pengaruh Perendaman Kosentrasi Asam Klorida dan Lama Perendaman terhadap Kualitas Gelatin yang Dihasilkan dari Limbah Kulit Belahan (split leather waste). Skripsi. Fakultas Peternakan. Institut Pertanian Bogor. Bogor.
Ward, A. G. and A. Courts. 1977. The Seience and Technology of Gelatin. Academis Press. New York. 